\title{
Mediation of humoral catecholamine secretion by the renin-angiotensin system in hypotensive rainbow trout (Oncorhynchus mykiss)
}

\author{
N J Bernier ${ }^{1}$, H Kaiya $^{2}$, Y Takei $^{2}$ and S F Perry ${ }^{1}$ \\ ${ }^{1}$ Department of Biology, University of Ottawa, 30 Marie Curie, Ottawa, Ontario, Canada K1N 6N5 \\ ${ }^{2}$ Laboratory of Physiology, Ocean Research Institute, The University of Tokyo, 1-15-1 Minamidai, Nakano, Tokyo 164-8639, Japan \\ (Requests for offprints should be addressed to SF Perry, Department of Biology, University of Ottawa, 30 Marie Curie, Ottawa, Ontario, Canada K1N 6N5)
}

\begin{abstract}
The individual contributions of, and potential interactions between, the renin-angiotensin system (RAS) and the humoral adrenergic stress response to blood pressure regulation were examined in rainbow trout. Intravenous injection of the smooth muscle relaxant, papaverine $(10 \mathrm{mg} / \mathrm{kg})$, elicited a transient decrease in dorsal aortic blood pressure $\left(P_{\mathrm{DA}}\right)$ and systemic vascular resistance $\left(R_{\mathrm{S}}\right)$, and significant increases in plasma angiotensin II (Ang II) and catecholamine concentrations. Blockade of $\alpha$-adrenoceptors before papaverine treatment prevented $P_{\mathrm{DA}}$ and $R_{\mathrm{S}}$ recovery, had no effect on the increase in plasma catecholamines, and resulted in greater plasma Ang II concentrations. Administration of the angiotensinconverting enzyme inhibitor, lisinopril $\left(10^{-4} \mathrm{~mol} / \mathrm{kg}\right)$, before papaverine treatment attenuated the increases in the plasma concentrations of Ang II, adrenaline, and noradrenaline by 90,79 , and $40 \%$, respectively and also prevented $P_{\mathrm{DA}}$ and $R_{\mathrm{S}}$ recovery. By itself, lisinopril
\end{abstract}

treatment caused a gradual and sustained decrease in $P_{\mathrm{DA}}$ and $R_{\mathrm{S}}$, and reductions in basal plasma Ang II and adrenaline concentrations. Bolus injection of a catecholamine cocktail (4 nmol $/ \mathrm{kg}$ noradrenaline plus $40 \mathrm{nmol} / \mathrm{kg}$ adrenaline) in the lisinopril + papaverine-treated trout, to supplement their circulating catecholamine concentrations and mimic those observed in fish treated only with papaverine, resulted in a temporary recovery in $P_{\mathrm{DA}}$ and $R_{\mathrm{S}}$. These results indicate that the RAS and the acute humoral adrenergic response are both recruited during an acute hypotensive stress, and have important roles in the compensatory response to hypotension in rainbow trout. However, whereas the contribution of the RAS to $P_{\mathrm{DA}}$ recovery is largely indirect and relies on an Ang IImediated secretion of catecholamines, the contribution from the adrenergic system is direct and relies at least in part on plasma catecholamines.

Journal of Endocrinology (1999) 160, 351-363

\section{Introduction}

Studies in comparative endocrinology point to a central role for the renin-angiotensin system (RAS) in the maintenance of blood pressure and fluid volume homeostasis among all classes of vertebrates (Wilson 1984, Henderson \& Deacon 1993, Kobayashi \& Takei 1996). Indeed, the vasopressor and dipsogenic actions of angiotensin II (Ang II), the biologically active product of the RAS, have been described in groups ranging from elasmobranchs to mammals. In teleost fish, a reduction in renal perfusion pressure, or in blood volume after hemorrhage, leads to an increase in the activity of plasma renin, the catalyst of the RAS cascade (Nishimura et al. 1979, Bailey \& Randall 1981), and plasma Ang II (Kobayashi et al. 1980). Similarly, administration of the hypotensive agent, papaverine, elicits an increase in plasma renin activity, plasma Ang II concentrations, and drinking rate (Nishimura et al. 1979, Balment \& Carrick 1985, Tierney et al. 1995). Preventing the formation of Ang II with an angiotensin-converting enzyme (ACE) inhibitor abolishes the papaverine-induced dipsogenic response and hinders recovery from the hypotensive stress (Balment \& Carrick 1985, Perrott \& Balment 1990, Tierney et al. 1995). Blockade of the RAS with an ACE inhibitor also has been shown to decrease resting blood pressure in a variety of teleost species (Olson 1992, Platzack et al. 1993, Tierney et al. 1995). Taken together, this evidence suggests that the RAS of teleosts has a tonic role in blood pressure regulation and mediates some of the physiological responses that counteract hypotensive stressors.

In addition to the RAS, an important contributor to cardiovascular control in teleosts is the sympathetic nervous system (SNS). Whereas resting blood pressure is under the control of an adrenergic tonus of neuronal origin, plasma catecholamines originating from the chromaffin tissue in the head kidney can provide an additional adrenergic influence on the cardiovascular system during 
periods of stress (Nilsson 1994, Bernier \& Perry 1999). Furthermore, experiments using $\alpha$-adrenoceptor blockade have shown that a significant component of the cardiovascular effects of exogenous Ang II injections is mediated indirectly via interactions with the SNS (Olson 1992, Platzack et al. 1993, Olson et al. 1994, Butler et al. 1995, Oudit \& Butler 1995, Bernier \& Perry 1999). However, the potential contributions of the SNS to cardiovascular control during a hypotensive stress have yet to be investigated in fish.

In rainbow trout (Oncorhynchus mykiss), there is mounting evidence that Ang II may be a potent activator of the humoral component of the SNS. In a preceding study, we have provided immunohistochemical evidence for the presence of Ang II binding sites on the catecholaminecontaining chromaffin cells of O. mykiss (Bernier \& Perry 1997). Moreover, bolus injections of homologous Ang II in trout elicit a dose-dependent release of catecholamines in an in situ perfusion preparation of the head kidney, and a dose-dependent increase in plasma adrenaline concentrations in vivo (Bernier \& Perry 1997, 1999). It is known that Ang II can exert a direct vasoconstrictor action in the systemic microcirculation of rainbow trout (Olson et al. 1994), but a portion of the cardiovascular effects of exogenous Ang II can also be attributed to increased concentrations of plasma adrenaline (Bernier \& Perry 1999). However, given that the cardiovascular effects of Ang II-mediated humoral catecholamines are recruited dose-dependently (Bernier \& Perry 1999), it remains to be ascertained whether endogenous recruitment of Ang II can elicit an increase in plasma catecholamines capable of contributing to cardiovascular homeostasis.

Therefore, the present study was undertaken to determine whether the acute humoral adrenergic stress response contributes to cardiovascular control after a hypotensive stress, and to assess the relative importance of the interactions between the RAS and the SNS for blood pressure regulation in rainbow trout.

\section{Materials and Methods}

\section{Experimental animals}

Rainbow trout (Oncorhynchus mykiss) of either sex were obtained from Linwood Acres Trout Farm (Campbellcroft, Ontario, Canada) and transported to the fish-rearing facilities of the University of Ottawa. The fish were held indoors in large fiberglass tanks supplied with flowing, aerated, and dechlorinated city water. The fish were maintained at a temperature of $13{ }^{\circ} \mathrm{C}$, on a $12 \mathrm{~h}$ light : $12 \mathrm{~h}$ darkness photoperiod cycle, and fed daily with a commercial salmonid diet. The trout of series 1 and 2 (see below) had a mean mass of $767 \cdot 9 \pm 21 \cdot 8 \mathrm{~g}$ (experimental $n=44)$ and $430 \cdot 0 \pm 8 \cdot 4 \mathrm{~g}$ (experimental $n=35$ ), respectively.

\section{Surgical procedures}

Rainbow trout were anesthetized in an oxygenated and buffered $\left(\mathrm{NaHCO}_{3} 0 \cdot 16 \mathrm{~g} / \mathrm{l}\right)$ solution of ethyl-maminobenzoate (0.08 g/1; MS-222; Syndel, Vancouver, $\mathrm{BC}$, Canada) until cessation of breathing movements. The fish were then transferred to an operating table, where the gills were force-ventilated with the same anesthetic solution. In series 1 , in order to measure dorsal aortic blood pressure $\left(P_{\mathrm{DA}}\right)$, fish were equipped with a dorsal aortic cannula (PE 50, Clay Adams, Becton Dickinson, Sparks, MD, USA; Soivio et al. 1975). To permit drug injections and repeated blood sampling, a lateral incision was made in the caudal peduncle to expose the caudal vein and dissect it free from overlying tissue, and to cannulate (PE 50) this vessel in the anterograde direction. In addition, the pericardial cavity was exposed with a midline ventral incision and the pericardium was dissected to expose the bulbus arteriosus. To allow measurement of cardiac output (Q), a $3 \mathrm{~S}$ or $4 \mathrm{~S}$ ultrasonic flow probe (Transonic Systems Inc., Ithaca, NY, USA) was placed non-occlusively around the bulbus. Lubricating jelly was used with the perivascular flow probe as an acoustic couplant. Silk sutures were used to close the ventral and caudal peduncle incisions, and to anchor the cardiac output probe lead and the caudal vein cannula to the skin. In series 2 , trout were anesthetized as above and equipped with a caudal vein cannula to permit drug injections and serial blood sampling. After surgery, all fish were placed into individual opaque boxes supplied with flowing water and left to recover for $24 \mathrm{~h}$ before experimentation. All cannulae were filled and flushed with teleost Cortland saline (Wolf 1963).

\section{Experimental protocol}

Series 1: effects of hypotension on cardiovascular control and plasma catecholamines Six separate experimental groups of rainbow trout were used to investigate the relative contributions of catecholamines and the renin-angiotensin system to cardiovascular control during a hypotensive stress. Trout were monitored during an initial period of 30-60 min to assess the stability of $P_{\mathrm{DA}}$ and $Q$ traces. Upon stabilization, control baseline cardiovascular parameters were recorded for $10 \mathrm{~min}$, after which trout were administered one of the following intravenous injection: (a) $0.9 \% \mathrm{NaCl}(0.375 \mathrm{ml} / \mathrm{kg})$ over a 10-min period (control treatment; $n=7$ ), (b) papaverine $(0.375 \mathrm{ml} / \mathrm{kg}$; RBI, Natick, MA, USA) at $10 \mathrm{mg} / \mathrm{kg}$ over a 10-min period (papaverine treatment; $n=8$ ), (c) papaverine $(0.375 \mathrm{ml} / \mathrm{kg})$ at $10 \mathrm{mg} / \mathrm{kg}$ over a $10-\mathrm{min}$ period after phenoxybenzamine (RBI) pretreatment (phenoxybenzamine + papaverine treatment; $n=6$ ), (d) lisinopril (1 ml/kg; Sigma Chemical, St Louis, MO, USA) at $10^{-4} \mathrm{~mol} / \mathrm{kg}$ over a $2-\mathrm{min}$ period (lisinopril treatment; $n=8$ ), (e) lisinopril $(1 \mathrm{ml} / \mathrm{kg})$ at $10^{-4} \mathrm{~mol} / \mathrm{kg}$ over a $2 \mathrm{~min}$ period followed, $10 \mathrm{~min}$ later, by an injection of 
papaverine $(0.375 \mathrm{ml} / \mathrm{kg})$ at $10 \mathrm{mg} / \mathrm{kg}$ over a $10-\mathrm{min}$ period (lisinopril+papaverine treatment; $n=8$ ), and (f) lisinopril $(1 \mathrm{ml} / \mathrm{kg})$ at $10^{-4} \mathrm{~mol} / \mathrm{kg}$ over a $2-\mathrm{min}$ period followed, $10 \mathrm{~min}$ later, by an injection of papaverine $(0.375 \mathrm{ml} / \mathrm{kg})$ at $10 \mathrm{mg} / \mathrm{kg}$ over a $10-\mathrm{min}$ period and, $7.5 \mathrm{~min}$ later, by a bolus injection of catecholamines $(4 \mathrm{nmol} / \mathrm{kg}$ noradrenaline bitartrate and $40 \mathrm{nmol} / \mathrm{kg}$ adrenaline bitartrate; Sigma; lisinopril+ papaverine + catecholamine treatment; $n=7)$. Each injection was followed by $0.2 \mathrm{ml}$ saline to clear the caudal vein cannula, and the cardiovascular effects of these treatments were monitored continuously over the following $90 \mathrm{~min}$. In each treatment, a blood sample $(0.3 \mathrm{ml})$ was taken at the end of the initial 10-min control baseline period, and at 10 , $15,20,25,30,40,50,60,70,80$, and $90 \mathrm{~min}$ into the treatment, for subsequent analysis of plasma catecholamines. Each blood sample was replaced by an equivalent volume of saline containing 3\% bovine serum albumin (BSA), collected in a microcentrifuge tube containing $5 \mu \mathrm{l}$ $10 \% \mathrm{Na}_{2}$-EDTA, and centrifuged immediately at $10000 \boldsymbol{g}$ for $15 \mathrm{~s}$. The separated plasma was quick frozen in liquid nitrogen and stored at $-80{ }^{\circ} \mathrm{C}$ for later analysis of catecholamines.

In the phenoxybenzamine+papaverine treatment, $\alpha$-adrenoceptor blockade was achieved by slowly (over a $15-\mathrm{min}$ period) giving two injections of $3 \mathrm{mg} / \mathrm{kg}$ phenoxybenzamine 12 and $6 \mathrm{~h}$ before experimentation. Phenoxybenzamine was dissolved in $100 \mu \mathrm{l}$ ethanol and diluted in saline before injection $(3 \mathrm{mg} / \mathrm{ml})$. The effectiveness of this protocol to achieve $\alpha$-adrenoceptor blockade in rainbow trout was confirmed previously (Bernier \& Perry 1999).

\section{Series 2: effects of hypotension on plasma Ang II}

Five of the experimental groups outlined in series 1 above were repeated in order to assess circulating concentrations of plasma $\left[\mathrm{Asn}^{1}, \mathrm{Val}^{5}\right]$-Ang II in hypotensive rainbow trout: (a) control treatment $(n=7)$, (b) papaverine treatment $(n=7)$, (c) phenoxybenzamine+papaverine treatment $(n=7)$, (d) lisinopril treatment $(n=7)$, and (e) lisinopril+ papaverine treatment $(n=7)$. In each treatment, a blood sample $(0 \cdot 15 \mathrm{ml})$ was taken at the end of the initial 10-min control baseline period, and at 10, 15, 20, 25, 30, 40, 50, 70, and $90 \mathrm{~min}$ into the treatment, for subsequent analysis of plasma $\left[\mathrm{Asn}^{1}, \mathrm{Val}^{5}\right]$-Ang II. Each blood sample was replaced by an equivalent volume of saline containing $3 \%$ BSA, collected in a microcentrifuge tube containing $5 \mu \mathrm{l} 10 \% \mathrm{Na}_{2}$-EDTA, and centrifuged immediately at $10000 \mathrm{~g}$ for $15 \mathrm{~s}$. The separated plasma was quick frozen in liquid nitrogen and stored at $-80{ }^{\circ} \mathrm{C}$ for later analysis of $\left[\mathrm{Asn}^{1}, \mathrm{Val}^{5}\right]$-Ang II.

Analytical procedures Dorsal artery pressure $\left(P_{\mathrm{DA}}\right)$ was measured with a UFI model 1050BP (UFI, Morro Bay, CA, USA) pressure transducer that was calibrated against a static water column. Mean blood pressure was calculated as: (systolic pressure + diastolic pressure) $/ 2$. The perivascular flow probes used to measure $Q$ were connected to a Transonic T106 small animal blood flow meter (Transonic Systems, Inc., Ithaca, NY, USA). These probes were precalibrated in the factory and verified in the laboratory by pump perfusion of the heart of an immersed euthanized fish, using saline at known flow rates. Both $P_{\mathrm{DA}}$ and $\mathrm{Q}$ signals were recorded with a data acquisition system (Biopac System Inc., Goleta, CA, USA) and collected at 0.04-s intervals using Acknowledge III (Biopac System Inc.) data acquisition software. Systemic vascular resistance $\left(R_{\mathrm{S}}\right)$ was calculated as mean $P_{\mathrm{DA}}$ divided by $\mathrm{Q}$ (i.e. $\left.R_{\mathrm{S}}=P_{\mathrm{DA}} / \mathrm{Q}\right)$.

Plasma catecholamines (adrenaline and noradrenaline) were determined on alumina-extracted plasma samples $(0.2 \mathrm{ml})$ using high-pressure liquid chromatography (HPLC) with electrochemical detection (Bernier \& Perry 1997). The extracted samples were passed through an Ultratechsphere ODS-C18 $5 \mu \mathrm{m}$ column (HPLC Technology Ltd), using a catecholamine and metanephrine mobile phase (Chromosystems, Munich, Germany). The separated amines were integrated using the Star Chromatography software program (version $4 \cdot 0$, Varian, Walnut Creek, CA, USA). Concentrations were calculated relative to appropriate standards and with 3,4dihydroxybenzylamine hydrobromide (DHBA) as an internal standard in all determinations.

Development and validation of a radioimmunoassay for trout Ang II Source of antisera and specificity. The antiserum used for the current radioimmunoassay (RIA) was initially raised against mammalian Ang II ([Asp $\left.{ }^{1}, \mathrm{Ile}^{5}\right]-$ Ang II; Yamaguchi 1981) and has previously been shown to exhibit a high degree of cross-reactivity with teleost Ang II ([Asn $\left.{ }^{1}, \mathrm{Val}^{5}\right]$-Ang II; Takei et al. 1988). In this study, the specificity of the antiserum was checked by comparing the standard curve obtained with $\left[\mathrm{Asp}^{1}, \mathrm{Ile}^{5}\right]-$ Ang II (Sigma) against those obtained with the following peptides: $\left[\mathrm{Asp}^{1}, \mathrm{Val}^{5}\right]$-Ang II (Sigma), $\left[\mathrm{Asn}^{1}, \mathrm{Val}^{5}\right]$ Ang II (Sigma), $\left[\mathrm{Asn}^{1}{ }^{1}, \mathrm{Pro}^{3}, \mathrm{Il}^{5}\right]$-Ang II (Peptide Institute Inc., Osaka, Japan), [Asp ${ }^{1}, \mathrm{Ile}^{5}$, His $\left.^{9}\right]-$ Ang I (Sigma), $\left[\mathrm{Asn}^{1}, \mathrm{Val}^{5}, \mathrm{Asn}^{9}\right]$-Ang I (Sigma), [Asn $\left.{ }^{1}, \mathrm{Val}^{5}, \mathrm{Gly}^{9}\right]-$ Ang I (Peninsula Laboratories, Belmont, CA, USA), and [Asn ${ }^{1}$, $\left.\mathrm{Pro}^{3}, \mathrm{Ile}^{5}, \mathrm{Gln}^{9}\right]$-Ang I (Peptide Institute). The crossreaction of these peptides with the Ang II antiserum was calculated as the ratio of the amount of $\left[\mathrm{Asp}^{1}, \mathrm{Ile}^{5}\right]-$ Ang II that produced $50 \%$ of ${ }^{125} \mathrm{I}$-Ang II bound to the amount of each peptide that produced $50 \%$ of ${ }^{125}$ I-Ang II bound.

The specificity of the antisera for $\left[\mathrm{Asn}^{1}, \mathrm{Val}^{5}\right]$-Ang II was also assessed by a combination of reverse-phase HPLC and RIA. In order to determine the elution position of standard ligands, 1-ml injection volumes of distilled water containing either $100 \mathrm{pmol}\left[\mathrm{Asn}^{1}, \mathrm{Val}^{5}\right]$-Ang II and $300 \mathrm{pmol}\left[\mathrm{Asn}^{1}, \mathrm{Val}^{5}, \mathrm{Asn}^{9}\right]-\mathrm{Ang} \mathrm{I}$ or $100 \mathrm{pmol}$ $\left[\mathrm{Asn}^{1}, \mathrm{Val}^{5}, \mathrm{Asn}{ }^{9}\right]$-Ang I, were subjected to reversephase HPLC. The standard ligands were applied to an 
ODS-120T column $(4.6 \times 250 \mathrm{~mm}$; Tosoh, Japan $)$ and eluted with a linear gradient from 10 to $60 \% \mathrm{CH}_{3} \mathrm{CH}$ in $0 \cdot 1 \%$ trifluoroacetic acid for $40 \mathrm{~min}$ at $1 \mathrm{ml} / \mathrm{min}$. A $0 \cdot 8-\mathrm{ml}$ trout plasma sample was extracted (see below for procedure), reconstituted in $1 \mathrm{ml}$ distilled water, and subjected to the same chromatographic separation as the standard ligands. Fractions of the eluted plasma sample were collected at 1-min intervals throughout the 40-min gradient. Each fraction was lyophilized, reconstituted in $1 \mathrm{ml}$ assay buffer, and analysed for immunoreactive Ang II with the RIA.

Procedures for radioimmunoassay. The RIA was performed by a double antibody method (Takei et al. 1992). The incubation mixture for the standard curve consisted of $0 \cdot 1 \mathrm{ml}$ standard $\left[\mathrm{Asn}^{1}, \mathrm{Val}^{5}\right]$-Ang II ligand, $0 \cdot 1 \mathrm{ml}$ Ang II antiserum (1:400 000 dilution), and $0 \cdot 1 \mathrm{ml}$ normal rabbit serum $(1 / 250$; Sigma). After the mixture had been allowed to stand for $20 \mathrm{~h}$ at $4{ }^{\circ} \mathrm{C}, 0.05 \mathrm{ml}{ }^{125}$ I-labelled $\left[\right.$ Asp $^{1}$, ,le $\left.^{5}\right]$-Ang II (approximately 5000 c.p.m.; specific activity, $2000 \mathrm{Ci} / \mathrm{mmol}$; Amersham) was added to the mixture and incubated for another $24 \mathrm{~h}$ at $4{ }^{\circ} \mathrm{C}$. Precipitation was then achieved with a combination of goat anti-rabbit IgG serum $(0 \cdot 1 \mathrm{ml} ; 1 / 40$ dilution; code 111 001-003; Jackson ImmunoResearch Laboratories, West Grove, PA, USA) and 16\% w/v polyethylene glycol 8000 $(0 \cdot 1 \mathrm{ml}$; Sigma). The resulting mixture was centrifuged at $1500 \mathrm{~g}$ for $60 \mathrm{~min}$ at $4{ }^{\circ} \mathrm{C}$ to separate the bound from the free ligands. The supernatant was discarded via aspiration, and the radioactivity in the precipitate was counted in a $\gamma$-counter (1271 RIAGamma, LKB) for $1 \mathrm{~min}$. In the incubation mixture of unknown samples, the $0.1 \mathrm{ml}$ of standard ligand was replaced with extracted trout plasma $(10-40 \mu \mathrm{l})$ diluted with assay buffer to a final volume of $0 \cdot 1 \mathrm{ml}$. The buffer used throughout the RIA consisted of: $10 \mathrm{mmol} / 1$ phosphate buffer, $\mathrm{pH} 7 \cdot 4$, containing $140 \mathrm{mmol} / \mathrm{l} \quad \mathrm{NaCl}, \quad 0 \cdot 1 \% \quad \mathrm{w} / \mathrm{v} \quad \mathrm{NaN}_{3}, \quad 40 \mathrm{mmol} / \mathrm{l}$ $\mathrm{K}_{2}$ EDTA, $10 \mathrm{mmol} / 1 \quad \varepsilon$-amino- $n$-caproic acid, $0.05 \%$ Triton X-100, and 1\% BSA. The amount of Ang II in the unknown samples was calculated using a three-parameter sigmoid curve regression equation (Sigma Plot; Jandel, San Rafael, CA, USA) obtained from the standard curve of $\left[\mathrm{Asn}^{1}, \mathrm{Val}^{5}\right]$-Ang II. All measurements were made in triplicate.

Extraction of plasma samples. Plasma samples were extracted according to the method of Phillips et al. (1991) with modifications. Briefly, $0 \cdot 1 \mathrm{ml}$ just-thawed plasma and acidic acetone (acetone $\left.-\mathrm{H}_{2} \mathrm{O}-1 \mathrm{~mol} / 1 \mathrm{HCl}, 40: 5: 1\right)$ were mixed and vortexed vigorously. The mixture was centrifuged for $10 \mathrm{~min}$ at $10000 \mathrm{~g}$ and $4{ }^{\circ} \mathrm{C}$. The supernatant was collected in a new tube and the pellet re-solubilized and re-extracted with $0 \cdot 1 \mathrm{ml}$ acidic acetone. Once combined, the supernatants were lyophilized. For the RIA, the extracted pellet was re-suspended in $0.1 \mathrm{ml}$ assay buffer. The recovery rate of Ang II through this extraction procedure, as measured with ${ }^{125} \mathrm{I}$-labelled $\left[\mathrm{Asn}^{1}, \mathrm{Val}^{5}\right]$ Ang II, was $89 \cdot 8 \%(n=6)$.
Table 1 Cross-reaction of Ang II antiserumt with a variety of angiotensin peptides

Cross-reaction

(\%)

\section{Peptide}

$\left[\right.$ Asp $^{1}$, lle $\left.^{5}\right]$-Ang II (mammalian)

$\left[\mathrm{Asp}^{1}, \mathrm{Val}^{5}\right]$-Ang II (tetrapod)

100

$\left[\right.$ Asn $\left.^{1}, \mathrm{Val}^{5}\right]$-Ang II (teleost)

$86 \cdot 5$

$\left[\mathrm{Asn}^{1}\right.$, Pro $\left.^{3}, \mathrm{ll}^{5}\right]$-Ang II (Triakis scyllia)‡

$\left[\right.$ Asp $\left.^{1}, \mathrm{ll}^{5}, \mathrm{His}^{9}\right]$-Ang I (mammalian)

$62 \cdot 7$

$73 \cdot 4$

$0 \cdot 32$

$\left[\right.$ Asn $^{1}, \mathrm{Val}^{5}, \mathrm{Asn}^{9}$ ]-Ang I (Oncorhynchus keta)§

$\left[\right.$ Asn ${ }^{1}, \mathrm{Val}^{5}$, Gly ${ }^{9}$ ]-Ang I (Anguilla japonica)

$0 \cdot 10$

$0 \cdot 16$

$\left[\mathrm{Asn}^{1}, \mathrm{Pro}^{3}, \mathrm{Ile}^{5}, \mathrm{Gln}^{9}\right]$-Ang I (Triakis scyllia)‡

†Yamaguchi (1981); ‡Takei et al. (1993); §Takemoto et al. (1983); THasegawa et al. (1983).

Statistical analyses Data are presented as mean \pm S.E.M. The statistical significance of the observed effects of an injection within a treatment was tested using a oneway repeated-measures analysis of variance (ANOVA). Dunnett's post-hoc multiple-comparison test was used to compare the pre-injection control data point with values at subsequent times. For a given parameter and time, differences between the control and papaverine treatments, or between the control and lisinopril treatments were assessed with $t$-tests. Differences among the four experimental groups treated with papaverine (papaverine, lisinopril+ papaverine, lisinopril+papaverine + catecholamine, and phenoxybenzamine+ papaverine) were assessed with a one-way ANOVA followed by Dunnett's multiplecomparisons test. The significance level for all statistical tests was $P<0 \cdot 05$.

\section{Results}

\section{Development and validation of an RIA for trout Ang II}

The standard curves obtained with tetrapod, teleost, and dogfish Ang II were virtually superimposable with the curve obtained with mammalian Ang II, indicating a high degree of cross-reaction of the antiserum for a wide spectrum of Ang II peptides (Table 1). In contrast, the cross-reactivity of the antiserum with mammalian, salmon, eel, and dogfish Ang I was almost negligible. The reversephase HPLC of the extracted trout plasma revealed that the major peak of immunoreactive Ang II (Fig. 1b) was observed at the position corresponding to the standard $\left[\mathrm{Asn}^{1}, \mathrm{Val}^{5}\right]$-Ang II ligand (Fig. 1a). Only a minor peak (Fig. 1b), representing $4 \cdot 75 \%$ of the total assayed immunoreactivity, corresponded to the standard $\left[\mathrm{Asn}^{1}, \mathrm{Val}^{5}, \mathrm{Asn}^{9}\right]$-Ang I ligand (Fig. 1a). The least detectable amount of Ang II in the RIA was $0 \cdot 1 \mathrm{fmol}$ per tube $(n=11 ; P=0 \cdot 03)$. The intra-assay and interassay coefficients of variation were $4 \cdot 81 \%(n=6)$ and $5 \cdot 09 \%(n=6)$, 

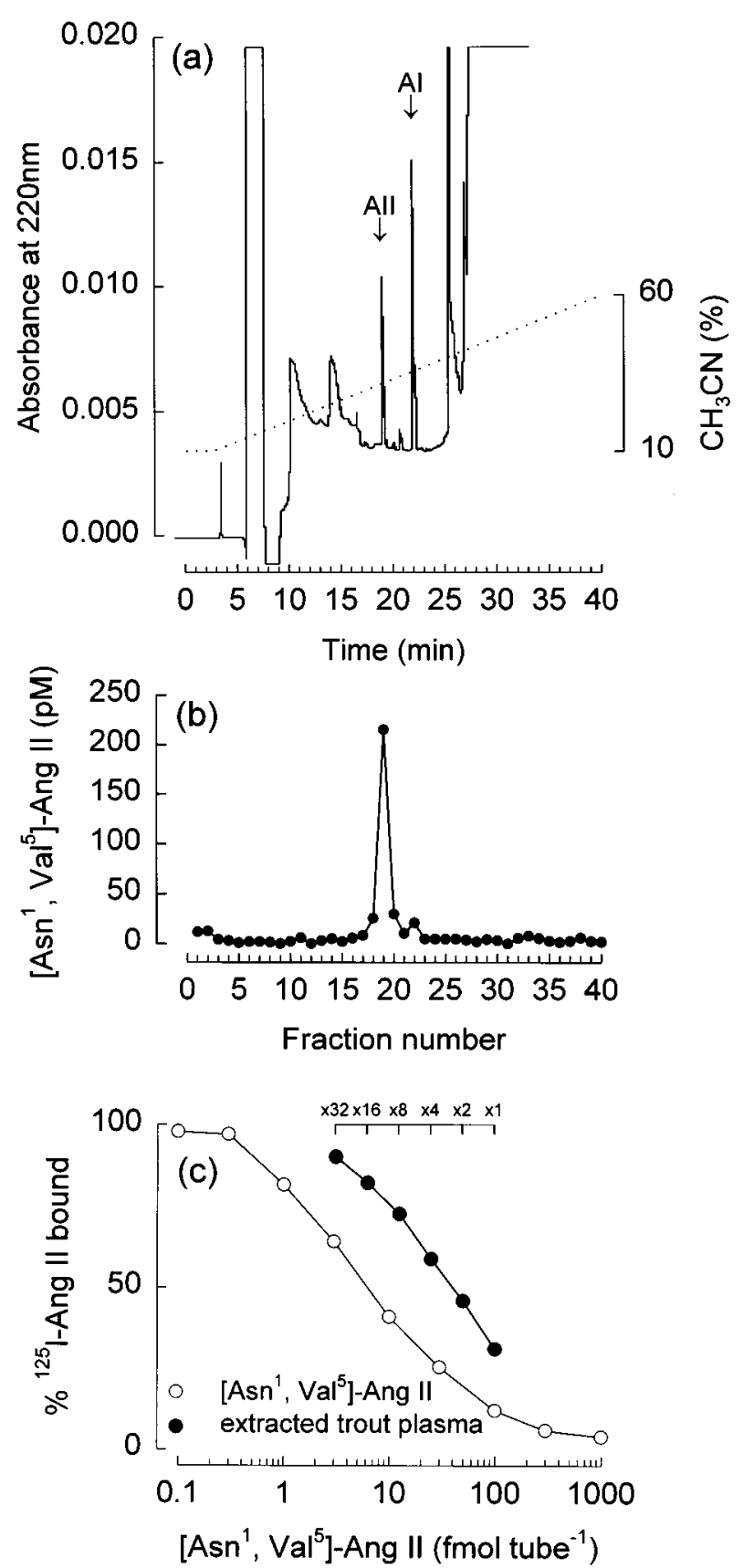

Figure 1 (a) Reverse-phase HPLC chromatogram of standard ligands. The dotted line shows linear gradient elution from 10 to $60 \% \mathrm{CH}_{3} \mathrm{CN}$ in $0 \cdot 1 \%$ trifluoroacetic acid. Flow rate was $1 \mathrm{ml} / \mathrm{min}$. Arrows indicate elution positions of $\left[\mathrm{Asn}^{1}, \mathrm{Val}^{5}\right]$-Ang II (AII) and $\left[\mathrm{Asn}^{1}, \mathrm{Val}^{5}, \mathrm{Asn}^{9}\right]$-Ang I (AI). (b) Elution pattern of immunoreactive $\left[\mathrm{Asn}^{1}, \mathrm{Val}^{5}\right]$-Ang II from extracted O. mykiss plasma submitted to reverse-phase HPLC. Elution conditions as in (a). Fraction size was $1 \mathrm{ml}$ per tube. (c) Standard curve for radioimmunoassay of $\left[\mathrm{Asn}^{1}, \mathrm{Val}^{5}\right]$-Ang II and serial dilution curve of extracted O. mykiss plasma. respectively. The dilution curve of immunoreacitve Ang II in extracted O. mykiss plasma was parallel to the standard curve of $\left[\mathrm{Asn}^{1}, \mathrm{Val}^{5}\right]$-Ang II (Fig. 1c).

Series 1 and 2: effects of hypotension on cardiovascular control, plasma catecholamines, and plasma Ang II

In the control treatment, intravenous injection of $0.9 \%$ $\mathrm{NaCl}$ and repeated blood sampling resulted in a small decrease in $P_{\mathrm{DA}}$ (Fig. 2a) and $R_{\mathrm{S}}$ (Fig. 3a) over the course of the experiment, and had no effect on Q (Fig. 4a). The injection of saline alone and the sampling protocol had no effect on basal plasma catecholamine (Fig. 5a) and Ang II concentrations (Fig. 6a).

The smooth muscle relaxant, papaverine, elicited a rapid decrease in $P_{\mathrm{DA}}$ (from $24.5 \pm 1.3$ to $11.9 \pm 1.2 \mathrm{mmHg}$ after $10 \mathrm{~min})$, followed by a full recovery $(24 \cdot 7 \pm$ $3.6 \mathrm{mmHg}$; Fig. 2b) only $25 \mathrm{~min}$ after the treatment. Papaverine treatment also elicited a rapid decrease in $R_{\mathrm{S}}$ (from $1 \cdot 0 \pm 0 \cdot 1$ to $0 \cdot 6 \pm 0 \cdot 1 \mathrm{mmHg} / \mathrm{ml} \mathrm{min}^{-1}$ per $\mathrm{kg}$ after $15 \mathrm{~min}$ ) with a full recovery after $30 \mathrm{~min}$ $\left(1 \cdot 0 \pm 0 \cdot 2 \mathrm{mmHg} / \mathrm{ml} \mathrm{min}^{-1}\right.$ per $\mathrm{kg}$; Fig. $\left.3 \mathrm{~b}\right)$, and a slower increase in $Q$ (from $25 \cdot 1 \pm 2.5$ to $32.6 \pm 1.6 \mathrm{ml}$ / min per $\mathrm{kg}$ after $50 \mathrm{~min}$; Fig. $4 \mathrm{~b}$ ). In addition, administering papaverine resulted in marked and sustained increases in plasma adrenaline (from $2 \cdot 2 \pm 0 \cdot 6$ to $588 \cdot 7 \pm 135 \cdot 1 \mathrm{nM}$ after $20 \mathrm{~min}$; Fig 5b), plasma noradrenaline (from $1.2 \pm 0.6$ to $139.9 \pm 32.9 \mathrm{nM}$ after 15 min; Fig. 5b) and plasma Ang II concentrations (from $125 \pm 12$ to $4098 \pm 1214$ pM after 20 min; Fig. 6b).

Fish treated with the $\alpha$-adrenergic blocker, phenoxybenzamine, had significantly lower $R_{\mathrm{S}}(0.6 \pm 0.1 \mathrm{mmHg} /$

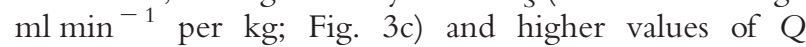
$(38.0 \pm 2.8 \mathrm{ml} / \mathrm{min}$ per $\mathrm{kg}$; Fig. $4 \mathrm{c})$ than $\mathrm{did}$ those in the papaverine treatment. Intravenous injection of papaverine in phenoxybenzamine-treated rainbow trout elicited rapid and sustained decreases in $P_{\mathrm{DA}}$ (from $21 \cdot 0 \pm 2 \cdot 0$ to $10 \cdot 2 \pm 0.5 \mathrm{mmHg}$ after $10 \mathrm{~min}$; Fig. $2 \mathrm{c}$ ) and $R_{\mathrm{S}}$ (from $0 \cdot 6 \pm 0 \cdot 1$ to $0 \cdot 3 \pm 0 \cdot 0 \mathrm{mmHg} / \mathrm{ml} \mathrm{min}^{-1}$ per $\mathrm{kg}$ after $15 \mathrm{~min}$; Fig. 3c), and sustained increases in $Q$ (from $38 \cdot 0 \pm 2 \cdot 8$ to $52 \cdot 2 \pm 4 \cdot 2 \mathrm{ml} / \mathrm{min}$ per $\mathrm{kg}$ after $50 \mathrm{~min}$; Fig. 4c) and in plasma concentrations of adrenaline (from $3 \cdot 2 \pm 0 \cdot 4$ to $516 \cdot 8 \pm 82 \cdot 0 \mathrm{nM}$ after $15 \mathrm{~min}$; Fig. $5 \mathrm{c}$ ), noradrenaline (from $1.9 \pm 0.5$ to $185 \cdot 0 \pm 37 \cdot 0 \mathrm{nM}$ after 15 min; Fig. 5c), and Ang II (from $188 \pm 55$ to $9866 \pm$ 1914 pM after 40 min; Fig. 6c). Overall, during recovery from the hypotensive stress in the phenoxybenzamine + papaverine treatment, $P_{\mathrm{DA}}$ and $R_{\mathrm{S}}$ values were significantly lower, and $Q$ and plasma Ang II values significantly higher than those obtained in the papaverine treatment.

Administration of the ACE inhibitor, lisinopril, produced gradual and sustained decreases in $P_{\mathrm{DA}}$ (from $24.6 \pm 0.9$ to $11.5 \pm 0.7 \mathrm{mmHg}$ after $100 \mathrm{~min}$; Fig. 2d) and $R_{\mathrm{S}}$ (from $1 \cdot 1 \pm 0 \cdot 1$ to $0 \cdot 4 \pm 0 \cdot 0 \mathrm{mmHg} / \mathrm{ml} \mathrm{min}^{-1}$ per kg after $100 \mathrm{~min}$; Fig. 3d), and no significant change in $Q$ (Fig. 4d). Whereas lisinopril treatment had no effect 

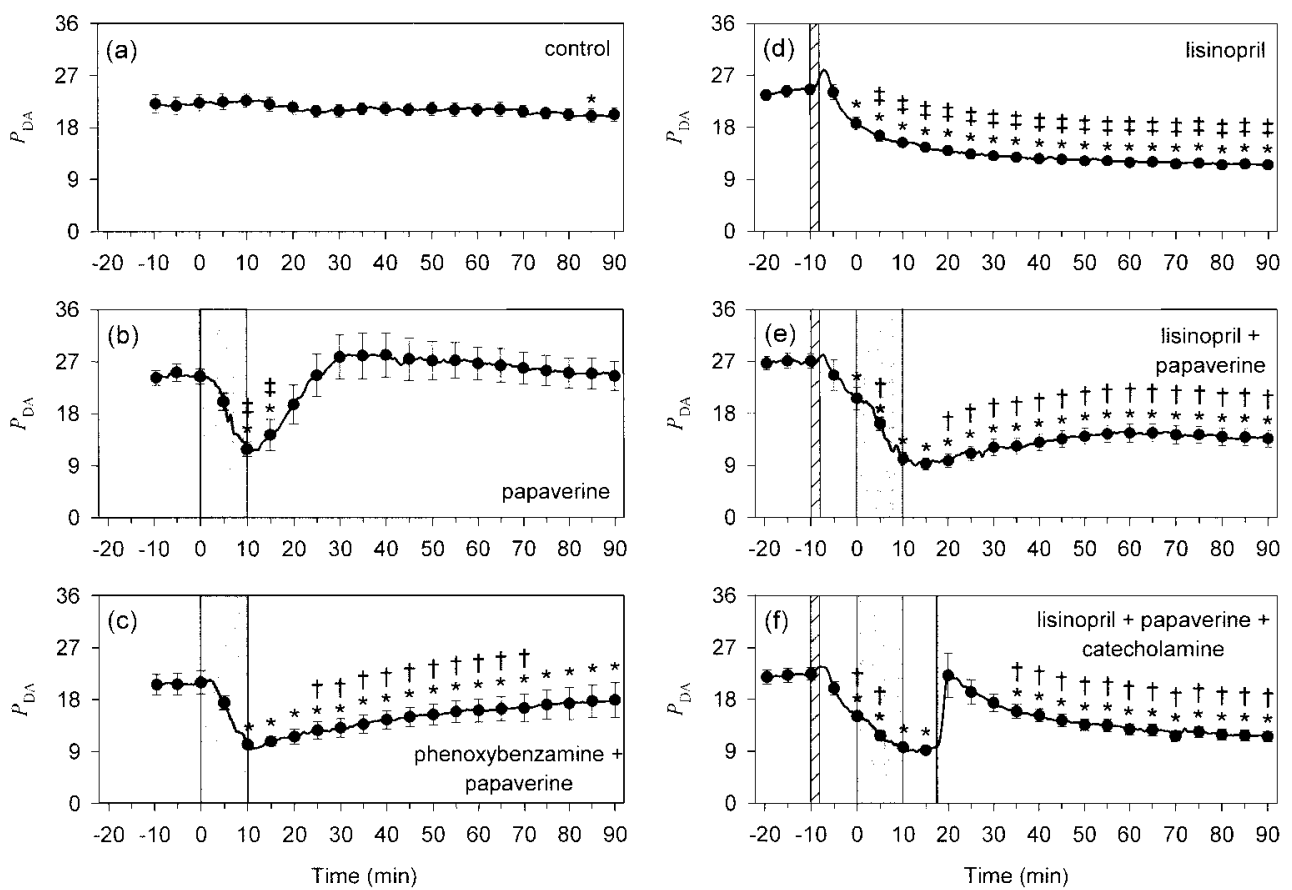

Figure 2 Time-course of changes in mean dorsal aortic pressure $\left(P_{\mathrm{DA}}, \mathrm{mmHg}\right)$ in rainbow trout administered (a) $0.9 \% \mathrm{NaCl}$ (control; $n=7$ ), (b) the smooth muscle relaxant, papaverine $(10 \mathrm{mg} / \mathrm{kg} ; n=8$ ), (c) papaverine $(10 \mathrm{mg} / \mathrm{kg})$ after pretreatment with the $\alpha$-adrenoceptor antagonist, phenoxybenzamine $(n=6),(\mathrm{d})$ the ACE inhibitor, lisinopril $\left(10^{-4} \mathrm{~mol} / \mathrm{kg} ; n=8\right)$, (e) lisinopril $\left(10^{-4} \mathrm{~mol} / \mathrm{kg}\right)$ followed by papaverine $(10 \mathrm{mg} / \mathrm{kg} ; n=8)$, or ( $\mathrm{f}$ ) lisinopril $\left(10^{-4} \mathrm{~mol} / \mathrm{kg}\right)$ followed by papaverine $(10 \mathrm{mg} / \mathrm{kg})$ and by a bolus of catecholamines ( $4 \mathrm{nmol} / \mathrm{kg}$ noradrenaline bitartrate and $40 \mathrm{nmol} / \mathrm{kg}$ adrenaline bitartrate; $n=7)$. The time during which papaverine was injected is shown by a gray box in graphs (b), (c), (e), and (f). The time during which lisinopril was injected is shown by a hatched bar in graphs (d), (e), and (f). The solid line in (f) indicates injection of catecholamines. For a given treatment: *significant difference from the 0-min value in graphs (a), (b), and (c), and from the -10 min value in graphs (d), (e), and (f); †significant difference from the corresponding value in the papaverine-treated (b) animals; $\ddagger$ significant difference from the corresponding value in the control (a) animals $(P<0 \cdot 05)$. Values are means \pm S.E.M.

on plasma noradrenaline concentrations, ACE blockade was characterized by chronic decreases in basal plasma adrenaline (from $2 \cdot 8 \pm 0 \cdot 3$ to $1 \cdot 1 \pm 0 \cdot 2 \mathrm{nM}$ after $25 \mathrm{~min}$; Fig. 5d) and plasma Ang II concentrations (from $166 \pm 28$ to $55 \pm 6 \mathrm{pM}$ after $25 \mathrm{~min}$; Fig. $6 \mathrm{~d}$ ).

Papaverine injection in lisinopril-treated fish elicited rapid and sustained decreases in $P_{\mathrm{DA}}$ (from $27 \cdot 1 \pm 1 \cdot 2$ to $9 \cdot 3 \pm 1 \cdot 0 \mathrm{mmHg}$ after $25 \mathrm{~min}$; Fig. $2 \mathrm{e}$ ) and $R_{\mathrm{S}}$ (from $1 \cdot 2 \pm 0 \cdot 1$ to $0 \cdot 4 \pm 0 \cdot 0 \mathrm{mmHg} / \mathrm{ml} \mathrm{min}^{-1}$ per $\mathrm{kg}$ after $30 \mathrm{~min}$; Fig. 3e), and a slower increase in $Q$ (from $24.5 \pm 2.3$ to $34.1 \pm 4.0 \mathrm{ml} / \mathrm{min}$ per $\mathrm{kg}$ after $60 \mathrm{~min}$; Fig. 4b). The combined lisinopril+papaverine treatment also produced sustained increases in plasma concentrations of adrenaline (from $2 \cdot 3 \pm 0 \cdot 9$ to $123.5 \pm 66 \cdot 2 \mathrm{nM}$ after $30 \mathrm{~min}$; Fig. 5e) and noradrenaline (from $2 \cdot 2 \pm 0 \cdot 6$ to $73 \cdot 8 \pm 27 \cdot 4 \mathrm{nM}$ after $20 \mathrm{~min}$; Fig. 5e), and a temporary increase in plasma Ang II concentration (from $124 \pm 29$ to $400 \pm 100 \mathrm{pM}$ after $40 \mathrm{~min}$; Fig. 6e). Overall, whereas the papaverine-elicited decreases in $P_{\mathrm{DA}}$ and $R_{\mathrm{S}}$ in the lisinopril-treated trout lasted longer and were more pro- nounced than those associated with the papaverine treatment, the increases in plasma catecholamines and Ang II concentrations in the lisinopril+papaverine-treated fish were significantly less than those observed with the papaverine treatment.

With the lisinopril+ papaverine + catecholamine treatment, changes in $P_{\mathrm{DA}}$ (Fig. 2f), $R_{\mathrm{S}}$ (Fig. 3f), $Q$ (Fig. 4f), and plasma adrenaline and noradrenaline concentrations (Fig. 5f) before the bolus injection of catecholamines were similar to those observed with the lisinopril+ papaverine treatment. The ensuing catecholamine injection temporarily increased plasma adrenaline (from $89 \cdot 6 \pm 18 \cdot 0$ to $663.7 \pm 56 \cdot 6 \mathrm{nM}$ ) and noradrenaline (from $28 \cdot 6 \pm 4 \cdot 4$ to $89 \cdot 1 \pm 15 \cdot 5 \mathrm{nM}$ ) concentrations to values comparable to those obtained with the papaverine treatment. This increase in circulating catecholamines was associated with a recovery in $P_{\mathrm{DA}}$, a transient increase in $R_{\mathrm{S}}$, and a faster increase in $Q$ than that observed with the lisinopril+papaverine treatment. However, as the catecholamine concentrations decreased once again to values 

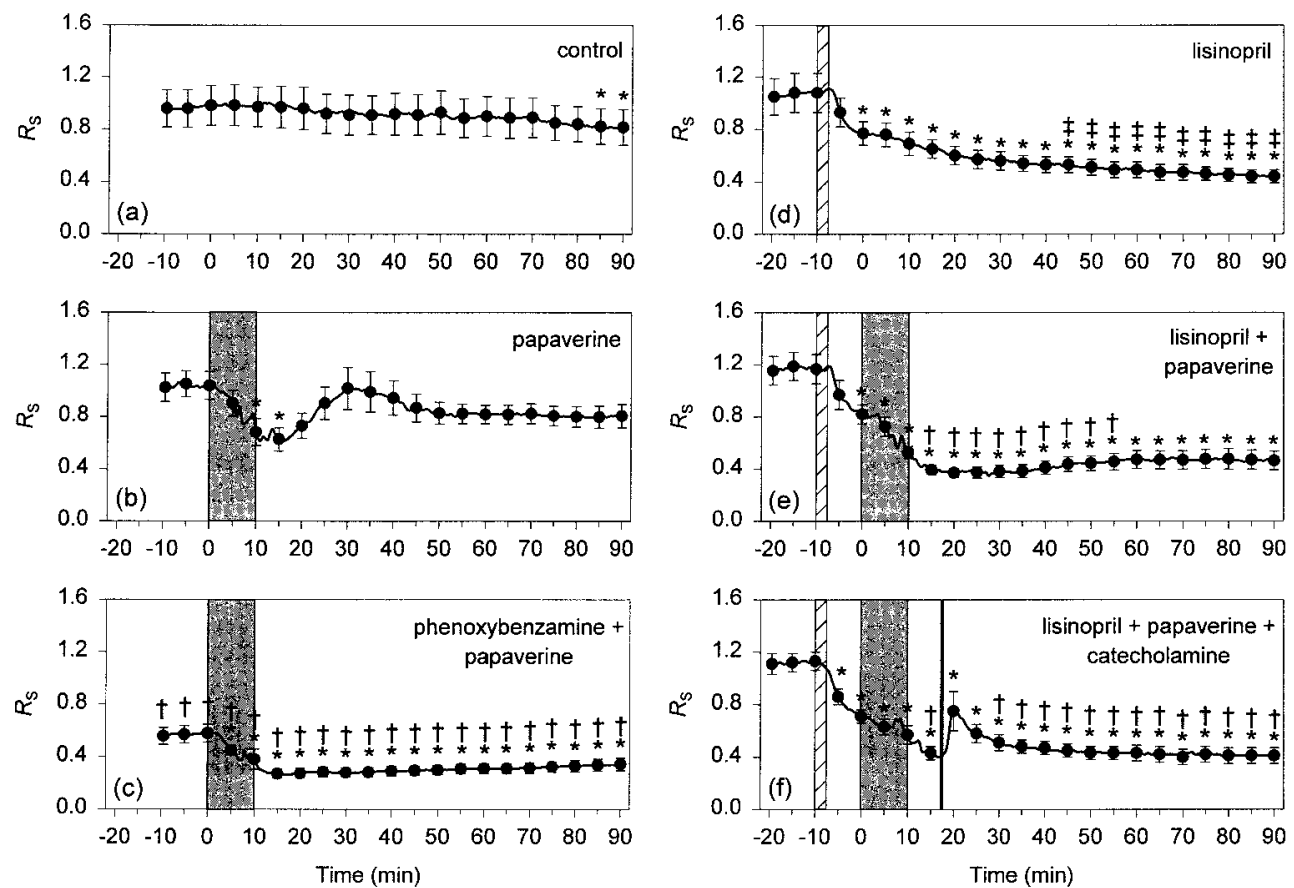

Figure 3 Time-course of changes in systemic vascular resistance $\left(R_{\mathrm{S}}, \mathrm{mmHg} / \mathrm{ml} \mathrm{min}^{-1}\right.$ per $\left.\mathrm{kg}\right)$ in rainbow trout administered (a) $0.9 \% \mathrm{NaCl}$ (control; $n=7$ ), (b) the smooth muscle relaxant, papaverine $(10 \mathrm{mg} / \mathrm{kg}$; $n=8)$, (c) papaverine $(10 \mathrm{mg} / \mathrm{kg})$ after pretreatment with the $\alpha$-adrenoceptor antagonist, phenoxybenzamine $(n=6)$, (d) the ACE inhibitor, lisinopril $\left(10^{-4} \mathrm{~mol} / \mathrm{kg} ; n=8\right)$, (e) lisinopril $\left(10^{-4} \mathrm{~mol} / \mathrm{kg}\right)$ followed by papaverine $(10 \mathrm{mg} / \mathrm{kg} ; n=8)$, or (f) lisinopril $\left(10^{-4} \mathrm{~mol} / \mathrm{kg}\right)$ followed by papaverine $(10 \mathrm{mg} / \mathrm{kg})$ and by a bolus of catecholamines $(4 \mathrm{nmol} / \mathrm{kg}$ noradrenaline bitartrate and $40 \mathrm{nmol} / \mathrm{kg}$ adrenaline bitartrate; $n=7)$. The time during which papaverine was injected is shown by a gray box in graphs (b), (c), (e), and (f). The time during which lisinopril was injected is shown by a hatched bar in graphs (d), (e), and (f). The solid line in (f) indicates injection of catecholamines. For a given treatment: *significant difference from the 0 -min value in graphs (a), (b), and (c), and from the -10 min value in graphs (d), (e), and (f); †significant difference from the corresponding value in the papaverine-treated (b) animals; $\ddagger$ significant difference from the corresponding value in the control (a) animals $(P<0 \cdot 05)$. Values are means \pm S.E.M.

significantly lower than those recorded in the papaverine treatment, there were parallel and sustained decreases in $P_{\mathrm{DA}}$ and $R_{\mathrm{S}}$.

\section{Discussion}

Results from the present study show that the RAS and the humoral component of the SNS are both recruited during an acute hypotensive stress in rainbow trout and have important roles in the compensatory response to hypotension. However, whereas blockade of the RAS prolonged a papaverine-induced hypotension and significantly reduced the recruitment of plasma catecholamines, inhibition of $\alpha$-adrenoceptors impeded the recovery of blood pressure, despite higher concentrations of plasma Ang II. Additional support for the importance of plasma catecholamines to blood pressure recovery after a hypotensive stress is provided by the observation that exogenous supplementation of plasma catecholamine concentrations prevents the chronic hypotensive effects of RAS blockade in papaverine-treated trout. This study provides therefore the first evidence that the acute humoral adrenergic stress response contributes to cardiovascular control during a hypotensive stress in fish, and suggests that a significant component of the RAS compensatory response to hypotension is mediated via interactions with the SNS.

As indicated by a marked increase in plasma Ang II concentrations, the RAS of rainbow trout is activated after treatment with the smooth muscle relaxant, papaverine. This result corroborates previous observations that papaverine treatment in fish can increase plasma renin activity (Nishimura et al. 1979) and plasma Ang II (Tierney et al. 1995), and supports the general contention that the RAS of teleosts can be activated by a reduction in blood pressure (Olson 1992). Relative to fish treated only with papaverine, the prolonged recovery of $P_{\mathrm{DA}}$ in ACEblocked and papaverine-treated trout (this study), eels (Anguilla anguilla; Tierney et al. 1995), and flounders (Platichthys flesus; Perrott \& Balment 1990), highlights the 

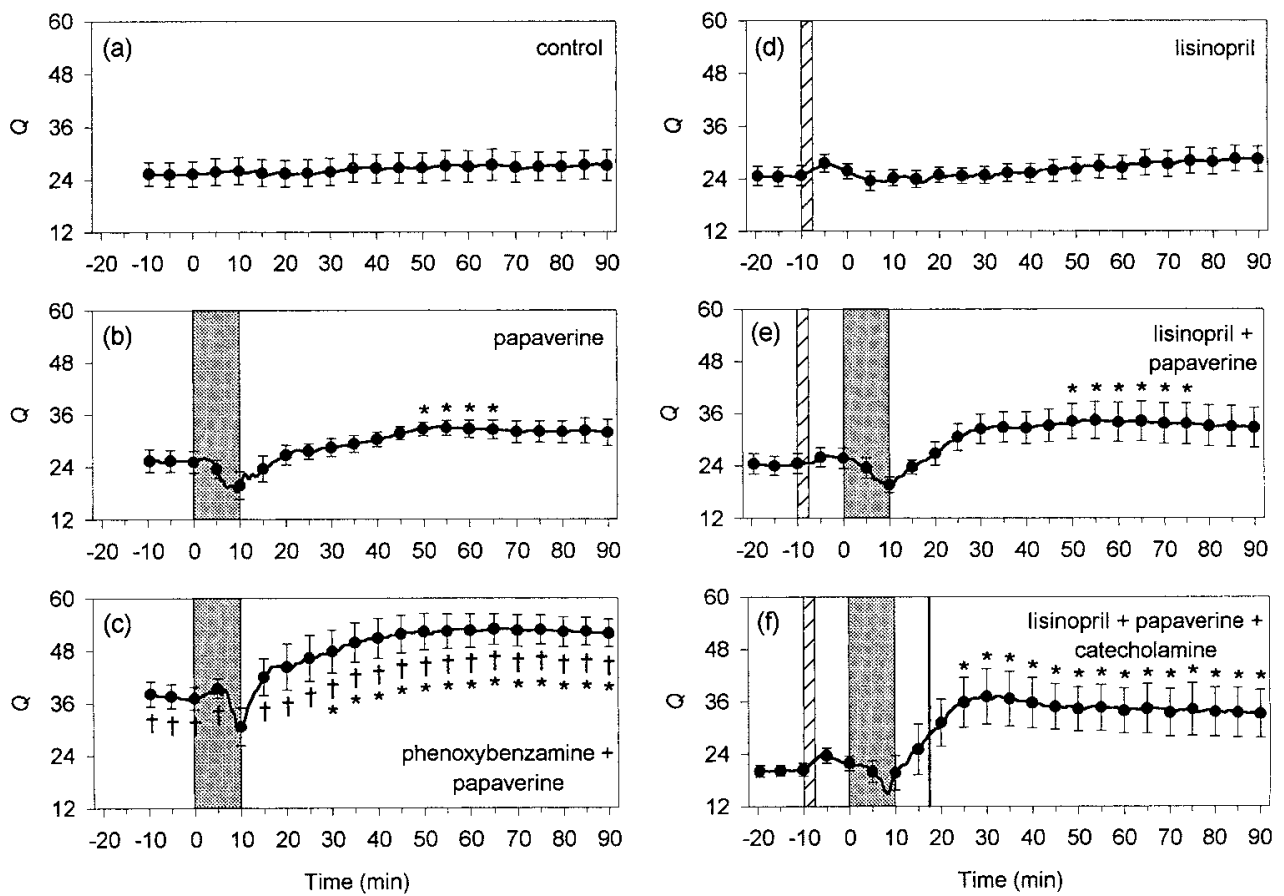

Figure 4 Time-course of changes in cardiac output $(Q, \mathrm{ml} / \mathrm{min}$ per $\mathrm{kg}$ ) in rainbow trout administered (a) $0.9 \% \mathrm{NaCl}$ (control; $n=7)$, (b) the smooth muscle relaxant, papaverine $(10 \mathrm{mg} / \mathrm{kg} ; n=8)$, (c) papaverine $(10 \mathrm{mg} / \mathrm{kg})$ after pretreatment with the $\alpha$-adrenoceptor antagonist, phenoxybenzamine $(n=6)$, (d) the ACE inhibitor, lisinopril $\left(10^{-4} \mathrm{~mol} / \mathrm{kg} ; n=8\right)$, (e) lisinopril $\left(10^{-4} \mathrm{~mol} / \mathrm{kg}\right)$ followed by papaverine $(10 \mathrm{mg} / \mathrm{kg}$; $n=8)$, or (f) lisinopril $\left(10^{-4} \mathrm{~mol} / \mathrm{kg}\right)$ followed by papaverine $(10 \mathrm{mg} / \mathrm{kg})$ and by a bolus of catecholamines $(4 \mathrm{nmol} / \mathrm{kg}$ noradrenaline bitartrate and $40 \mathrm{nmol} / \mathrm{kg}$ adrenaline bitartrate; $n=7$ ). The time during which papaverine was injected is shown by a gray box in graphs (b), (c), (e), and (f). The time during which lisinopril was injected is shown by a hatched bar in graphs (d), (e), and (f). The solid line in (f) indicates injection of catecholamines. For a given treatment: *significant difference from the 0 -min value in graphs $(a)$, (b), and (c), and from the -10 min value in graphs (d), (e), and (f); †significant difference from the corresponding value in the papaverine-treated (b) animals $(P<0 \cdot 05)$. Values are means \pm S.E.M.

importance to blood pressure restoration of an increase in plasma Ang II after a hypotensive stress. The dipsogenic and antidiuretic effects of Ang II in fish (Tierney et al. 1995, Kobayashi \& Takei 1996, Brown \& Balment 1997), and the contribution of Ang II to $R_{\mathrm{S}}$ in trout (Olson et al. 1994, Bernier \& Perry 1998), all suggest that the RAS may contribute directly to blood pressure regulation during hypotensive conditions. In contrast, in trout, because the RAS does not affect venous capacitance (Zhang et al. 1995) and Ang II has no inotropic or chronotropic effects in the in situ perfused heart (Olson et al. 1994), the RAS is unlikely to contribute directly to the increase in $Q$ after papaverine treatment.

The efficacy of lisinopril as an ACE inhibitor in the present study is similar to that previously observed for ACE inhibitors both in fish (Tierney et al. 1995) and in mammals (Campbell 1996). The incomplete inhibition of Ang II formation despite ACE blockade in the combined lisinopril+ papaverine treatment has previously been observed using a similar experimental protocol in Anguilla anguilla (Tierney et al. 1995). Mammalian studies have shown that tissue-specific differences in the efficacy of ACE inhibitors, alternative pathways of Ang II formation, and marked increase in circulating renin and Ang I concentrations may all contribute to the incomplete inhibition of ACE after clinical doses of ACE inhibitors (Campbell 1996). In fish, as in mammals (Campbell 1996), renin secretion by the kidney is subject to negative feedback regulation by Ang II (Bailey \& Randall 1981). Therefore, ACE inhibitors result in increased renin secretion and increased angiotensin peptide formation.

The hypotensive effects of papaverine, in addition to stimulating the RAS, resulted in a marked increase in the circulating concentrations of plasma catecholamines. In fact, relative to other studies that monitored plasma catecholamines after various types of stress (Randall \& Perry 1992, Thomas \& Perry 1992), the magnitude of the increase in plasma catecholamines after papaverine treatment suggests that hypotension may be one of the most potent activators of the humoral adrenergic stress response in fish. Because overflow from peripheral nerve terminals does not appear to contribute significantly to the increase 

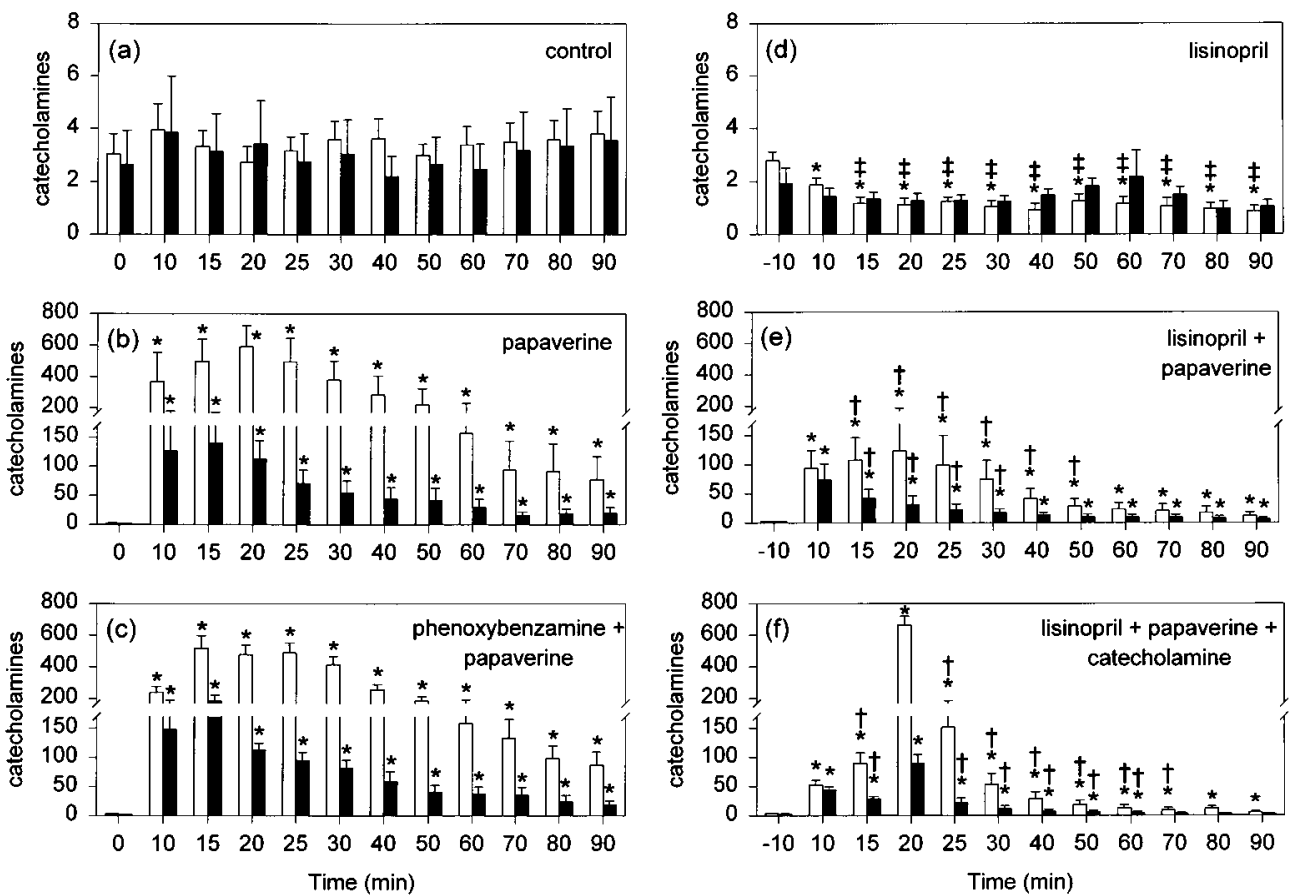

Figure 5 Time-course of changes in plasma catecholamines (nM), adrenaline (unfilled bars) and noradrenaline (filled bars), in rainbow trout administered (a) $0.9 \% \mathrm{NaCl}$ (control; $n=7$ ), (b) the smooth muscle relaxant, papaverine $(10 \mathrm{mg} / \mathrm{kg} ; n=8)$, (c) papaverine $(10 \mathrm{mg} / \mathrm{kg})$ after pretreatment with the $\alpha$-adrenoceptor antagonist, phenoxybenzamine $(n=6)$, (d) the ACE inhibitor, lisinopril $\left(10^{-4} \mathrm{~mol} / \mathrm{kg} ; n=8\right)$, (e) lisinopril $\left(10^{-4} \mathrm{~mol} / \mathrm{kg}\right)$ followed by papaverine $(10 \mathrm{mg} / \mathrm{kg} ; n=8)$, or (f) lisinopril $\left(10^{-4} \mathrm{~mol} / \mathrm{kg}\right)$ followed by papaverine $(10 \mathrm{mg} / \mathrm{kg})$ and by a bolus of catecholamines $(4 \mathrm{nmol} / \mathrm{kg}$ noradrenaline bitartrate and $40 \mathrm{nmol} / \mathrm{kg}$ adrenaline bitartrate; $n=7$ ). Saline, papaverine and lisinopril injections were carried out before the 10-min sampling time. In (f), the injection of catecholamines took place at $17.5 \mathrm{~min}$. For a given treatment: ${ }^{*}$ significant difference from the 0 -min value in graphs (a), (b), and (c), and from the -10 min value in graphs (d), (e), and (f); †significant difference from the corresponding value in the papaverine-treated (b) animals; $\ddagger$ significant difference from the corresponding value in the control (a) animals $(P<0 \cdot 05)$. Values are means + S.E.M.

in plasma catecholamine concentrations in fish (Perry et al. 1991), the increase in plasma catecholamines after an acute hypotensive stress most probably originates from the chromaffin tissue in the head kidney. Whereas catecholamine secretion from the chromaffin tissue in fish is generally associated with an acute reduction in blood oxygen content (Randall \& Perry 1992, Reid et al. 1998), this study provides evidence that acute hypotension can result in an activation of the humoral adrenergic stress response independent of blood oxygen status. Previous experiments have demonstrated that increases in circulating plasma adrenaline concentrations of equivalent or smaller magnitude than those observed in the papaverinetreated fish can contribute significantly to cardiovascular control in O. mykiss by increasing $P_{\mathrm{DA}}, R_{\mathrm{S}}$, and $\mathrm{Q}$ (Gamperl et al. 1994, Bernier \& Perry 1999). In support of these results, the present study showed that exogenous catecholamine supplementation in the lisinopril+ papaverine treated fish leads to a temporary recovery in $P_{\mathrm{DA}}$ and $R_{\mathrm{S}}$ that is similar to the recovery experienced by fish treated with papaverine only. Overall, despite a pronounced increase in $Q$ and in plasma Ang II concentrations, the blunted $P_{\mathrm{DA}}$ recovery and chronic depression in $R_{\mathrm{S}}$ after papaverine treatment in $\alpha$-adrenoceptorblocked fish suggest that the SNS has a key role in the compensatory response of rainbow trout to a hypotensive stress.

In support of previous investigations that established Ang II as a secretagogue of catecholamine release in rainbow trout (Bernier \& Perry 1997, 1999), the current results suggest that an endogenous increase in plasma Ang II can stimulate the secretion of catecholamines from the chromaffin tissue. Whereas papaverine treatment elicited parallel increases in plasma Ang II and catecholamine concentrations, ACE blockade before papaverine treatment attenuated the increase in the plasma concentrations of Ang II, adrenaline, and noradrenaline by 90, 79, and $40 \%$, respectively. The preferential inhibition of plasma adrenaline with ACE blockade in papaverine-treated fish suggests that Ang II may be a more potent secretagogue of 

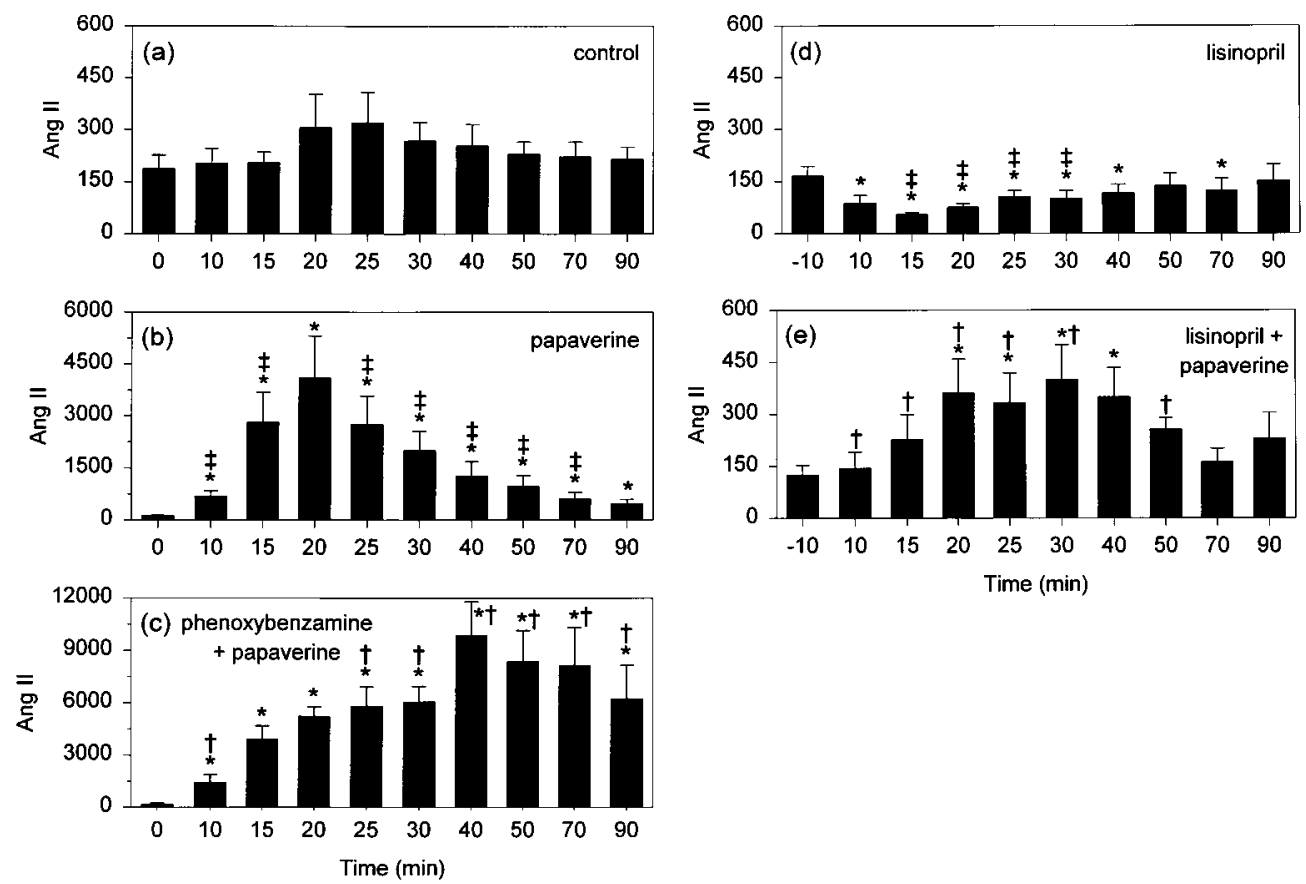

Figure 6 Time-course of changes in plasma $\left[\mathrm{Asn}^{1}, \mathrm{Val}{ }^{5}\right]$-Ang II (pM) in rainbow trout administered (a) $0.9 \%$ $\mathrm{NaCl}$ (control; $n=7)$, (b) the smooth muscle relaxant, papaverine $(10 \mathrm{mg} / \mathrm{kg} ; n=7)$, (c) papaverine $(10 \mathrm{mg} / \mathrm{kg})$ after pretreatment with the $\alpha$-adrenoceptor antagonist, phenoxybenzamine $(n=7)$, (d) the ACE inhibitor, lisinopril $\left(10^{-4} \mathrm{~mol} / \mathrm{kg} ; n=7\right)$, or (e) lisinopril $\left(10^{-4} \mathrm{~mol} / \mathrm{kg}\right)$ followed by papaverine $(10 \mathrm{mg} / \mathrm{kg} ; n=7)$. Saline, papaverine and lisinopril injections were carried out before the 10-min sampling time. For a given treatment: ${ }^{*}$ significant difference from the 0-min value in graphs (a), (b), and (c), and from the -10 min value in graphs (d), and (e); tsignificant difference from the corresponding value in the papaverine-treated (b) animals; łsignificant difference from the corresponding value in the control (a) animals $(P<0 \cdot 05)$. Values are means + S.E.M.

adrenaline secretion than of noradrenaline secretion. This is consistent with the much greater increase in plasma adrenaline than in noradrenaline after papaverine treatment, and with previous observations showing that bolus injections of Ang II, either in situ or in vivo, elicit a preferential secretion of adrenaline in fish (Carroll \& Opdyke 1982, Bernier \& Perry 1997, 1999). Given that adrenaline, but not noradrenaline, has substantial effects on venous function in trout (Zhang et al. 1998), the greater impact of Ang II on adrenaline than on noradrenaline secretion may be physiologically relevant to the indirect effects of the RAS on venous return, and therefore $Q$ and blood pressure.

Whereas the increase in plasma Ang II was accompanied by increases in plasma catecholamines in the papaverine-treated fish, significantly greater and sustained concentrations of Ang II in the phenoxybenzamine+ papaverine treatment did not result in greater plasma catecholamine concentrations. These results contrast with the previously observed Ang II-mediated dose-dependent release of catecholamines from the chromaffin tissue of trout (Bernier \& Perry 1997, 1999), and suggest either a potential desensitization of the catecholamine secretion process after chronic stimulation by Ang II or an inhibitory influence of $\alpha$-adrenoceptor blockade on catecholamine release from the chromaffin tissue. Although desensitization of catecholamine release from the chromaffin tissue of trout has been observed previously after repeated stress (Reid et al. 1994, Perry et al. 1996), the inhibitory effects of $\alpha$-adrenoceptor blockade on catecholamine release in Anguilla rostrata (Abele et al. 1998) have yet to be investigated in trout.

Although Ang II can directly elicit catecholamine secretion from the chromaffin tissue in both fish (Bernier \& Perry 1997) and mammals (Reid 1992), Ang II can also stimulate the adrenal medullary response via the central nervous system in the latter (Corwin et al. 1985, Reid 1992). Because Ang II has known central actions in trout, via specific Ang II binding sites (Pamantung et al. 1997), it is possible that at least part of the increase in plasma catecholamines after hypotension is mediated via central effects of Ang II. In addition, because ACE blockade was associated only with a partial reduction of the hypotensionelicited increase in plasma catecholamines, secretagogues other than Ang II are probably involved in stimulating catecholamine release during a hypotensive stress in trout. 
Stimulation of catecholamine release via preganglionic cholinergic fibers is one such possibility, but a variety of non-cholinergic secretagogues may also have a role in the overall control of catecholamine release after an acute stress in teleosts (Reid et al. 1988).

The RAS, in addition to stimulating catecholamine release from the chromaffin tissue, is known to interact with the SNS of vertebrates at the level of the sympathetic nerves (Wilson 1984, Reid 1992). In rainbow trout, approximately $40 \%$ of the vasoconstrictory effect of Ang II in a perfused trunk preparation is abolished by the adrenergic nerve toxin, bretylium (Olson et al. 1994). Thus it is likely that a portion of the Ang II pressor response is mediated via sympathetic nerves. Similarly, perfusion experiments in the Atlantic cod (Gadus morhua) also suggest that Ang II may modulate sympathetic nerves by facilitating the release of catecholamines (Platzack 1995). In the present study, although we did not specifically assess the possible interactions between the RAS and sympathetic nerves in trout, the reduction in basal adrenaline concentrations that were observed with ACE inhibition suggests that the RAS may tonically stimulate the release of adrenaline from sympathetic nerves or the chromaffin tissue, or both. Specific effects of Ang II on sympathetic nerves have yet to be assessed in rainbow trout, but we have previously observed that ACE inhibition decreases the basal release of both adrenaline and noradrenaline secretion from in situ head kidney preparations of O. mykiss (Bernier \& Perry 1997). Because basal plasma adrenaline concentrations may be an important source of neuronal catecholamine uptake and may be required to sustain neuronal sympathetic tone $(\mathrm{Xu} \&$ Olson 1993), our results suggest that the RAS may modulate sympathetic nerve activity indirectly via a tonic stimulation of catecholamine release from the chromaffin tissue. Hence, in addition to the direct role of Ang II in maintaining systemic arteriolar resistance (Olson et al. 1994, Zhang et al. 1995), a number of different interactions between the RAS and the SNS may explain, at least in part, the hypotensive effects of ACE blockade in resting trout.

The chronic hypotensive effects of ACE blockade observed in this study concur with similar observations in rainbow trout (Olson et al. 1997a) and other teleosts (Olson 1992, Platzack et al. 1993, Tierney et al. 1995). Unlike other hypotensive treatments (e.g. papaverine, phenoxybenzamine), ACE blockade in trout is not associated with a reflexive increase in $Q$ (this study; Olson et al. 1997a). The absence of a compensatory increase in $Q$ to stabilize blood pressure after ACE blockade is a characteristic feature of ACE inhibitor therapy in mammals (Squire \& Reid 1992). Although the mechanisms involved in the cardiac response to ACE blockade remain unclear, the available data in mammals suggest that ACE inhibition reduces sympathetically mediated baroreflex responses while augmenting those that are parasympathetically mediated (Squire \& Reid 1992). In trout, given that intracerebroventricular injections of Ang II appear to stimulate heart rate via inhibitory effects on cardiac vagal motor neuron activity (Le Mével et al. 1994, Pamantung et al. 1997), the cardiac effects of ACE blockade may be mediated by mechanisms similar to those obtained in mammals.

ACE blockade, in addition to preventing the conversion of Ang I to Ang II, also inhibits the inactivation of the biologically active component of the kallikrein-kinin system, bradykinin (Olson 1992). Therefore, lisinopril treatment may be expected to increase plasma bradykinin concentrations. In trout, bolus injections of homologous bradykinins produce multiphasic effects on arterial blood pressure (Conlon et al. 1996, Olson et al. 1997b). In addition to producing pressor effects, bradykinins can mediate a depressor response by stimulating the release of vasodilator prostanoids by the resistance vessels (Olson et al. 1997b). Hence, it is possible that the vasodilatory effect of bradykinins may contribute to the hypotensive effect of ACE inhibition by lisinopril.

Whereas previous studies have shown that exogenous Ang II can elicit an increase in plasma catecholamines in fish (Carroll \& Opdyke 1982, Bernier \& Perry 1999), we have provided evidence that a hypotension-induced endogenous increase in plasma Ang II can quickly stimulate the release of large quantities of catecholamines. Furthermore, our data suggest that resting concentrations of plasma Ang II may assist in the regulation of basal catecholamine secretion from the chromaffin tissue of trout. The physiological significance of maintaining circulating catecholamine concentrations for blood pressure regulation has been discussed previously (Xu \& Olson 1993); however, the marked increase in plasma catecholamines associated with the acute hypotensive stress of this study may only be relevant during conditions of acute hemorrhage that are life threatening. Whether recruitment of the RAS under less severe physiological conditions, such as transfer to a hyperosmotic environment (Kobayashi et al. 1980) or exercise-induced hypotension (Platzack et al. 1993), also involves interactions with the SNS should be examined in future investigations. It should also be noted that, whereas Ang II stimulates catecholamine release in teleosts, there is no evidence for the opposite effect. Unlike the situation in mammals, in which the adrenergic nervous system plays a part in the control of renin release (Kobayashi \& Takei 1996), in teleosts catecholamines do not contribute to renin release from the juxtaglomerular cells (Bailey \& Randall 1981, Nakamura et al. 1992).

Overall, the role of the RAS in mediating the physiological response to a hypotensive stress in trout is akin to the critical role of the mammalian RAS in the defense against hemorrhagic hypotension (Robertson 1992). In mammals, this defense is achieved, not only via the direct pressor effect of Ang II and its interactions with the neuronal and humoral components of the SNS, but also 
through an Ang II stimulation of aldosterone and, possibly, vasopressin (Robertson 1992). Although aldosterone is typically absent in fish (Kobayashi \& Takei 1996), the circulating concentrations of arginine vasotocin (the homolog of mammalian vasopressin) increase after hemorrhage or Ang II injections in fresh-water eels (Henderson et al. 1985), and papaverine treatment in flounders (Brown $\&$ Balment 1997). Because arginine vasotocin is a potent vasopressor and antidiuretic hormone in fish (Le Mével et al. 1993, Brown \& Balment 1997, Conklin et al. 1997), it may also make a significant contribution to the restoration of blood pressure after a hypotensive stress in trout. In addition, a number of other vasoactive factors secreted from the endothelial cells of the vasculature, for example endothelins (Olson et al. 1991), may also be recruited in response to stress and contribute to cardiovascular homeostasis. Therefore, despite their key role in blood pressure regulation, the physiological effects of Ang II and plasma catecholamines in cardiovascular homeostasis should not be viewed in isolation.

In conclusion, we have presented evidence for an Ang II-mediated secretion of plasma catecholamines after an acute hypotensive stress in rainbow trout. A physiological significance of this interaction is suggested by the finding that ACE blockade before a hypotensive treatment substantially reduced the contribution of the chromaffin tissue and prevented restoration of blood pressure. Reliance of the RAS on the SNS for full expression of it pressor attributes is also suggested by the observations that $\alpha$-adrenoceptor blockade prevents recovery from hypotension despite increased Ang II concentrations, and that exogenous catecholamine supplementation supports blood pressure recovery in ACE-blocked trout.

\section{Acknowledgements}

We would like to thank Drs D L Brown, D Hickey, and $\mathrm{T}$ W Moon for the use of their equipment for the RIA measurements of plasma Ang II concentrations. We are also grateful to Dr K Yamaguchi for supplying us with the angiotensin II antiserum. This study was supported by the NSERC of Canada operating and equipment grants to S F P. N J B was the recipient of an Ontario Graduate Scholarship.

\section{References}

Abele B, Hathaway CB, Nibbio B \& Epple A 1998 Electrostimulation of catecholamine release in the eel: modulation by antagonists and autocrine agonists. General and Comparative Endocrinology 109 366-374.

Bailey JR \& Randall DJ 1981 Renal perfusion pressure and renin secretion in the rainbow trout, Salmo gairdneri. Canadian Journal of Zoology 59 1220-1226.

Balment RJ \& Carrick S 1985 Endogenous renin-angiotensin system and drinking behaviour in flounder. American Journal of Physiology 248 R157-R160.
Bernier NJ \& Perry SF 1997 Angiotensins stimulate catecholamine release from the chromaffin tissue of the rainbow trout. American Journal of Physiology 273 R49-R57.

Bernier NJ \& Perry SF 1999 Cardiovascular effects of angiotensin II-mediated adrenaline release in rainbow trout. Journal of Experimental Biology (In press).

Brown JA \& Balment RJ 1997 Teleost renal function: regulation by arginine vasotocin and by angiotensins. In Ionic Regulation in Animals, pp 150-164. Eds N Hazon, FB Eddy \& G Flik. Berlin: Springer.

Butler DG, Oudit GY \& Cadinouche MZA 1995 Angiotensin I- and II- and norepinephrine-mediated pressor responses in an ancient holostean fish, the bowfin (Amia calva). General and Comparative Endocrinology 98 289-302.

Campbell DJ 1996 Endogenous angiotensin II levels and the mechanism of action of angiotensin-converting enzyme inhibitors and angiotensin receptor type 1 antagonists. Clinical and Experimental Pharmacology and Physiology 23 (Suppl 3) S125-S131.

Carroll RG \& Opdyke DF 1982 Evolution of angiotensin II-induced catecholamine release. American Journal of Physiology 243 R54-R69.

Conklin DJ, Chavas A, Duff DW, Weaver L, Zhang Y \& Olson KR 1997 Cardiovascular effects of arginine vasotocin in the rainbow trout Oncorhynchus mykiss. Journal of Experimental Biology 200 2821-2832.

Conlon JM, Le Mével J-C, Conklin D, Weaver L, Duff DW \& Olson KR 1996 Isolation and cardiovascular activity of a second bradykinin-related peptide $\left(\left(\operatorname{Arg}^{0}, \operatorname{Trp}^{5}, \mathrm{Leu}^{8}\right)\right.$ bradykinin) from trout. Peptides 17 531-537.

Corwin EJ, Seaton JF, Hamaji M \& Harrison TS 1985 Central role for angiotensin in control of adrenal catecholamine secretion. American Journal of Physiology 248 R363-R370.

Gamperl AK, Pinder AW \& Boutilier RG 1994 Effect of coronary ablation and adrenergic stimulation on in vivo cardiac performance in trout (Oncorhynchus mykiss). Journal of Experimental Biology 186 $127-143$.

Hasegawa Y, Nakajima T \& Sokabe H 1983 Chemical structure of angiotensin formed with kidney renin in the Japanese eel, Anguilla japonica. Biomedical Research 4 417-420.

Henderson IW \& Deacon CF 1993 Phylogeny and comparative physiology of the renin-angiotensin system. In The ReninAngiotensin System vol 1, pp 2·1-2·28. Eds JIS Robertson \& MG Nicholls. London: Gower Medical Publishing.

Henderson IW, Hazon N \& Hughes K 1985 Hormones, ionic regulation and kidney function in fishes. In Physiological Adaptations of Marine Animals, pp 245-265. Ed MS Laverack. Cambridge: The Company of Biologists.

Kobayashi H \& Takei Y 1996 The Renin-Angiotensin System, Comparative Aspects, pp 53-75 \& 114-172. Berlin: Springer.

Kobayashi H, Uemura H \& Takei Y 1980 Physiological role of the renin-angiotensin system during dehydration. In Avian Endocrinology, pp 319-330. Eds A Epple \& MH Stetson. New York: Academic Press.

Le Mével J-C, Pamantung T-F, Mabin D \& Vaudry H 1993 Effects of central and peripheral administration of arginine vasotocin and related neuropeptides on blood pressure and heart rate in the conscious trout. Brain Research $\mathbf{6 1 0} 82-89$.

Le Mével J-C, Pamantung T-F, Mabin D \& Vaudry H 1994 Intracerebroventricular administration of angiotensin II increases heart rate in the conscious trout. Brain Research 654 216-222.

Nakamura Y, Madey MA, Nishimura H, Quach D \& Barajas L 1992 Lack of control of renin release by adrenergic nervous system in the aglomerular toadfish. General and Comparative Endocrinology $\mathbf{8 8}$ $62-75$.

Nilsson S 1994 Evidence for adrenergic nervous control of blood pressure in teleost fish. Physiological Zoology 67 1347-1359.

Nishimura H, Lunde LG \& Zucker A 1979 Renin response to hemorrhage and hypotension in the aglomerular toadfish Opsanus tau. American Journal of Physiology 237 H105-H111. 
Olson KR 1992 Blood and extracellular fluid volume regulation: role of the renin-angiotensin, kallikrein-kinin system, and atrial natriuretic peptides. In Fish Physiology vol XII, part B, pp 136-254. Eds WS Hoar, DJ Randall \& AP Farrell. San Diego: Academic Press Inc.

Olson KR, Duff DW, Farrell AP, Keen J, Kellogg MD, Kullman D \& Villa J 1991 Cardiovascular effects of endothelin in trout. American Journal of Physiology $260 \mathrm{H} 1214-\mathrm{H} 1223$.

Olson KR, Chavez A, Conklin DJ, Cousins KL, Farrell AP, Ferlic R, Keen JE, Kne T, Kowalski KA \& Veldman T 1994 Localization of angiotensin II responses in the trout cardiovascular system. Journal of Experimental Biology 194 117-138.

Olson KR, Conklin DJ, Farrell AP, Keen JE, Takei Y, Weaver L Jr, Smith MP \& Zhang Y 1997a Effects of natriuretic peptides and nitroprusside on venous function in trout. American Journal of Physiology 273 R527-R539.

Olson KR, Conklin DJ, Weaver L, Duff DW, Herman CA, Wang X \& Conlon JM $1997 b$ Cardiovascular effects of homologous bradykinin in rainbow trout. American Journal of Physiology 272 R1112-R1120.

Oudit GY \& Butler DG 1995 Angiotensin II and cardiovascular regulation in a freshwater teleost, Anguilla rostrata LeSueur. American Journal of Physiology 269 R726-R735.

Pamantung TF, Leroy J-P, Mabin D \& Le Mével J-C 1997 Role of dorsal vagal motor nucleus in angiotensin II-mediated tachycardia in the conscious trout Oncorhynchus mykiss. Brain Research $\mathbf{7 7 2}$ 167-175.

Perrott MN \& Balment RJ 1990 The renin-angiotensin system and the regulation of plasma cortisol in the flounder, Platichthys flesus. General and Comparative Endocrinology 78 414-420.

Perry SF, Fritsche R, Kinkead R \& Nilsson S 1991 Control of catecholamine release in vivo and in situ in the Atlantic cod (Gadus morhua) during hypoxia. Journal of Experimental Biology 155 549-566.

Perry SF, Reid SG \& Salama A 1996 The effects of repeated physical stress on the $\beta$-adrenergic response of the rainbow trout red blood cell. Journal of Experimental Biology 199 549-562.

Phillips MI, Kimura B \& Riazada MK 1991 Measurement of brain peptides: angiotensin and atrial natriuretic peptide in tissue and cell culture. In Methods in Neurosciences, Neuropeptide Technology: Sysnthesis, Assay, Purification, and Processing vol 6, pp 177-206. Ed PM Conn. London: Academic Press Inc.

Platzack B 1995 Blood pressure control by the renin-angiotensin system and its interaction with the sympathetic nervous system in fish. Brazilian Journal of Medical and Biological Research 28 1227-1231.

Platzack B, Axelsson M \& Nilsson S 1993 The renin-angiotensin system in blood pressure control during exercise in the cod Gadus morhua. Journal of Experimental Biology 180 253-262.

Randall DJ \& Perry SF 1992 Catecholamines. In Fish Physiology vol XIIB, part A, pp 255-300. Eds DJ Randall, WS Hoar \& AP Farrell. San Diego: Academic Press Inc.

Reid IA 1992 Interactions between Ang II, sympathetic nervous system, and baroreceptor reflexes in regulation of blood pressure. American Journal of Physiology 262 E763-E778.

Reid SG, Furimsky M \& Perry SF 1994 The effects of repeated physical stress or fasting on catecholamine storage and release in the rainbow trout, Oncorhynchus mykiss. Journal of Fish Biology 45 $365-378$.
Reid SG, Bernier NJ \& Perry SF 1998 The adrenergic stress response in fish: control of catecholamine storage and release. Comparative Biochemistry and Physiology 120 1-27.

Robertson JIS 1992 The renin-angiotensin system and the response to hemorrhage. In The Renin-Angiotensin System vol 2, pp 71·1-71·13. Eds JIS Robertson \& MG Nicholls. London: Gower Medical Publishing.

Soivio A, Nynolm K \& Westman K 1975 A technique for repeated sampling of the blood of individual resting fish. Journal of Experimental Biology 62 207-217.

Squire IB \& Reid JI 1992 Interactions between the renin-angiotensin system and the autonomic nervous system. In The Renin-Angiotensin System vol 1, pp. 37·1-37·16. Eds JIS Robertson \& MG Nicholls. London: Gower Medical Publishing.

Takei Y, Okubo J \& Yamaguchi K 1988 Effects of cellular dehydration on drinking and plasma angiotensin II level in eel, Anguilla japonica. Zoological Science 5 43-51.

Takei Y, Ando K \& Kawakami M 1992 Atrial natriuretic peptide in eel plasma, heart and brain characterized by homologous radioimmunoassay. Journal of Endocrinology 135 325-331.

Takei Y, Hasegawa TX, Watanabe K, Nakajima K \& Hazon N 1993 A novel angiotensin I isolated from an elasmobranch fish. Journal of Endocrinology 139 281-285.

Takemoto Y, Nakajima T, Hasegawa Y, Watanabe TX, Sokabe H, Kumagae S-I \& Sakakibara S 1983 Chemical structures of angiotensins formed by incubating plasma with the kidney and the corpuscles of stannius in the chum salmon, Oncorhynchus keta. General and Comparative Endocrinology 51 219-227.

Thomas S \& Perry SF 1992 Control and consequences of adrenergic activation of red blood cell $\mathrm{Na}^{+} / \mathrm{H}^{+}$exchange on blood oxygen and carbon dioxide transport in fish. Journal of Experimental Zoology 263 $160-175$.

Tierney ML, Luke G, Cramb G \& Hazon N 1995 The role of the renin-angiotensin system in the control of blood pressure and drinking in the european eel, Anguilla anguilla. General and Comparative Endocrinology 100 39-48.

Wilson JX 1984 The renin-angiotensin system in nonmammalian vertebrates. Endocrine Reviews 5 45-61.

Wolf K 1963 Physiological salines for fresh-water teleosts. The Progressive Fish-Culturist 25 135-140.

Xu HY \& Olson KR 1993 Significance of circulating catecholamines in regulation of trout splanchnic vascular resistance. Journal of Experimental Zoology 267 92-96.

Yamaguchi K 1981 Effects of water deprivation on immunoreactive angiotensin II levels in plasma, cerebroventricular perfusate and hypothalamus of the rat. Acta Endocrinologica 97 137-144.

Zhang Y, Jenkinson E \& Olson KR 1995 Vascular compliance and mean circulatory filling pressure in trout: effects of ACE inhibition. American Journal of Physiology 268 H1814-H1820.

Zhang Y, Weaver L, Ibeawuchi A \& Olson KR 1998 Catecholaminergic regulation of venous function in the rainbow trout. American Journal of Physiology 274 R1195-R1202.

Received 20 July 1998

Accepted 13 October 1998 